\title{
REASONS FOR DENTAL VISITS OF CHILDREN AND THEIR PARENTS AT THE DENTAL CLINICS IN CRACOW
}

\section{PRZYCZYNY ZGŁASZANIA SIĘ DZIECI I ICH RODZICÓW DO KRAKOWSKICH GABINETÓW STOMATOLOGICZNYCH}

\author{
${ }^{1}$ Department of Integrated Dentistry, Jagiellonian University Medical College \\ Katedra Stomatologii Zintegrowanej, Uniwersytet Jagielloński Collegium Medicum \\ ${ }^{2}$ Chair of Periodontology and Clinical Oral Pathology, Jagiellonian University Medical College \\ Katedra i Zakład Periodontologii i Klinicznej Patologii Jamy Ustnej, Uniwersytet Jagielloński Collegium Medicum
}

\section{ABSTRACT}

INTRODUCTION. Caries is a social disease that affects both children and adults. Parents have a significant influence on the formation of pro-health habits and the state of their children's oral health.

AIM OF THE PAPER. The main aim of the study was to assess the reasons why children and their parents come to the dental office. In addition, the condition of the teeth, the type of performed procedures and the correlation of the oral health between children and their parents were assessed.

MATERIAL AND METHODS. During the study, 162 patient's charts were analyzed from two different dental offices in Crakow. There were 81 parent-child pairs (one child per parent) who were treated in the same dental office between 2004 and 2018. During the first patient visit (parent or child) in the office, the reason for the visit and condition of patient teeth were evaluated. This analysis was based on the dental diagram using the DMF/ dmf (Decay-Missing-Filled) Index. Data regarding performed medical procedures during each office visit were collected and documented.

RESULTS. In most cases, children came to the dental clinic because of a toothache or cavities caused by caries (75.3\%). None of children were ever seen in the dental office for an initial adaptation visit under the age of two. During the first visit, caries was confirmed in $72 \%$ of children and $95 \%$ of parents. Correlation between child's $\mathrm{DMF} / \mathrm{DMF}+\mathrm{dmf} / \mathrm{dmf}$ and its parent's $\mathrm{DMF}$ indicated a positive linear relationship between these two variables $(\mathrm{r}=0.348, \mathrm{p}=0.001)$. The increase in the total number of children visits to the dental clinic was associated with the increase in the number of visits of their parents $(\mathrm{r}=0.327, \mathrm{p}=0.003)$. The most often performed medical procedures were check-ups (98.8\% children and $53.1 \%$ parents) and fillings of the permanent teeth (65.4\% children and $85.2 \%$ adults).

CONCLUSIONS. The majority of patients came to the dental clinic because of caries and its complications, not prophylactic procedures. Condition of the tooth hard tissue for both children and parents was less than satisfactory. There is a positive linear correlation between the state of patient dental health and the regularity and frequency of visits to the dental clinic for children and their parents.

Key words: caries, child, parents

\section{STRESZCZENIE}

WSTĘP. Próchnica jest chorobą społeczną, która dotyczy zarówno dzieci jak i osób dorosłych. Rodzice w znacznym stopniu mają wpływ na kształtowanie nawyków prozdrowotnych i stan zdrowia jamy ustnej swoich dzieci. CEL PRACY. Głównym celem pracy była ocena przyczyn zgłaszania się dzieci i ich rodziców do gabinetu stomatologicznego. Dodatkowo u dzieci i rodziców oceniano stan uzębienia, rodzaj wykonywanych zabiegów, a także zależność pomiędzy stanem zdrowia jamy ustnej u dzieci i ich rodziców.

MATERIAŁ I METODY. W badaniu przeanalizowano 162 karty pacjentów z dwóch krakowskich gabinetów stomatologicznych. Było to 81 par rodzic-dziecko (jedno dziecko przypadało na jednego rodzica) leczących 
się w tym samym gabinecie, których wizyty odbywały się w latach 2004-2018. Na pierwszej wizycie oceniano przyczyny zgłaszania się dzieci i ich rodziców do gabinetu stomatologicznego, stan zdrowia zębów przy pomocy wskaźnika PUW/puw/PUW+puw u dziecka i PUW u rodzica oraz rodzaj wykonanego zabiegu u każdego pacjenta. Na każdej wizycie oceniano rodzaj wykonywanych zabiegów u dziecka oraz rodzica.

WYNIKI. W większości przypadków dzieci zgłaszały się do gabinetu z powodu bólu zęba lub obecności ubytków próchnicowych (75,3\%), a żadne z nich nie odbyło wizyty adaptacyjnej w gabinecie poniżej 2 roku życia. Podczas pierwszej wizyty obecność próchnicy stwierdzono u 72\% dzieci i 95\% rodziców. Liczba PUW/puw/ PUW+puw u dziecka korelowała dodatnio z liczbą PUW u rodzica $(r=0,348, p=0,001)$. Wzrost liczby wizyt dziecka $\mathrm{w}$ gabinecie stomatologicznym wiązał się ze wzrostem liczby wizyt rodzica $\mathrm{w}$ gabinecie $(\mathrm{r}=0,327$, $\mathrm{p}=0,003)$. Najczęściej wykonywanymi procedurami były przegląd stomatologiczny $(98,8 \%$ dzieci i $53,1 \%$ dorosłych) oraz wypełnienie zęba stałego (65,4\% dzieci i 85,2\% dorosłych).

WNIOSKI. Większość pacjentów zgłaszała się do gabinetu stomatologicznego z powodu próchnicy i jej powikłań, a nie na wizyty profilaktyczne. Stan tkanek twardych zębów zarówno u dzieci jak i rodziców był niezadowalający. Istnieje związek pomiędzy stanem zdrowia zębów a także regularnością i liczbą wizyt w gabinecie pomiędzy dziećmi i ich rodzicami.

Słowa kluczowe: próchnica, dziecko, rodzice

\section{INTRODUCTION}

Caries is one of the most common diseases in the world, which is why the aim of modern dentistry is to reduce its occurrence. Therefore, the dental community emphasises prevention and particularly focuses on patients in developmental age. Caries is linked to the presence of carious bacteria in the oral cavity, a high-carbohydrate diet, the susceptibility of tooth tissues and length of exposure to caries factors. The development of tooth decay is also influenced by behavioural and socio-economic components (1).

Prophylaxis can significantly contribute to a reduction in caries incidence, as it promotes a noncariogenic diet, proper hygienic habits and the importance of regular visits to a dental office (2).

The oral health of children depends to a large extent on their caregivers, as they are responsible for teaching them and supervising tooth brushing, the child's diet and eating habits (3). Also, the bacterial flora of children's oral cavity is similar to that of their parents (4). Studies indicate that the main cariesforming bacterial species - Streptococcus mutans, can be transmitted from the caregiver to the child through a contact with saliva. Mothers are most likely to be the main source of a bacterial infection (5).

Parents are also responsible for the first contact of the child with a dentist. They determine the regularity of the child's visits to a dental clinic and help to build the relationship between the dentist and the young patient, thus partially influencing the child's future attitude to a dental treatment (3). Patients usually do not visit dental offices for regular preventive check-ups, unless they experience pain. The relevant literature recommends that the first visit of a child to a dentist should occur within 6 months after the eruption of first

\section{WSTĘP}

Próchnica jest jedną z najbardziej rozpowszechnionych chorób na świecie, dlatego też, celem współczesnej stomatologii jest ograniczenie jej występowania. W związku z tym środowisko stomatologiczne dużą wagę przywiązuje do prewencji i skupia się szczególnie na pacjentach $\mathrm{w}$ wieku rozwojowym. Pojawienie się próchnicy jest związane z obecnością bakterii próchnicotwórczych w jamie ustnej, dużą zawartością węglowodanów w diecie, podatnością tkanek zęba i czasem działania czynników próchnicotwórczych. Na rozwój próchnicy zębów mają wpływ także czynniki behawioralne i społeczno-ekonomiczne (1).

Profilaktyka ma duży wpływ na obniżenie zapadalności na próchnicę, gdyż promuje niekariogenną dietę, uczy prawidłowych nawyków higienicznych oraz podkreśla jak ważne są regularne wizyty w gabinecie dentystycznym (2).

Zdrowie jamy ustnej dzieci w dużym stopniu zależy od ich opiekunów, ponieważ to oni są odpowiedzialni za naukę i nadzorowanie szczotkowania zębów, dietę dziecka i kształtowanie nawyków żywieniowych (3). Także flora bakteryjna jamy ustnej dzieci jest zbliżona do flory bakteryjnej ich rodziców (4). Badania wskazują na to, że główny próchnicotwórczy gatunek bakterii - Streptococcus mutans może być przenoszony od opiekuna na dziecko poprzez kontakt ze śliną. Najprawdopodobniej to przede wszystkim matki są głównym źródłem infekcji bakteryjnej u swoich dzieci (5).

Rodzice są odpowiedzialni także za pierwszy kontakt dziecka z lekarzem dentystą. Decydują o regularności wizyt dziecka $\mathrm{w}$ gabinecie i pomagają budować relację lekarza z małym pacjentem, a tym samym częściowo wpływają na przyszłe nastawienie dziecka do leczenia stomatologicznego (3). Pacjenci do gabinetów 
milk teeth (6). Unfortunately, it does not happen. Most often, parents bring their child to the dentist for the first time because of a toothache. This kind of behaviour leads to lack of trust and reluctance of collaborations between young patients and dentists (7).

\section{THE AIM OF THE PAPER}

The main aim of the study was to assess reasons why children and their parents visit dental offices. Moreover, additional research goals were established:

1. evaluation of dental conditions of children and their parents,

2. assessment of performed dental procedures of participating children and their parents,

3. determination of correlations between parents and their child in terms of the condition of the oral cavity and performed medical procedures.

\section{MATERIAL AND METHODS}

During the study, 162 patient's charts were analyzed from two different dental offices in Crakow. There were 81 parent-child pairs (one child per parent) who were treated in the same dental office. Patient visits took place between 2004 and 2018 in two dental offices which had a contract with the National Health Fund (Narodowy Fundusz Zdrowia). During the first patient visit (parent or child) in the office, the reason for the visit was analyzed. The condition of patient teeth was also analyzed. This analysis was based on the dental diagram using the DMF/dmf (Decay-Missing-Filled) Index. The DMF/dmf indicates the sum of all cavities $(\mathrm{D} / \mathrm{p})$, number of extracted teeth $(\mathrm{M} / \mathrm{m})$ and total number of fillings $(\mathrm{F} / \mathrm{f})$. The DMF index refers to permanent teeth, the dmf refers to primary teeth, while the sum of both indicators (DMF and dmf) is used to determine the condition of both dentition types combined. The DMF index was assessed for adult patients, while the $\mathrm{dmf}$ and $\mathrm{DMF}+\mathrm{dmf}$ was used for children. Data regarding performed medical procedures during each office visit was collected and documented.

Each group, children and their parents, was subjected to a separate as well as combined statistical analysis. The continuous variables were presented in the form of medians and interquartile ranges. The categorical variables were shown in the form of numbers and percentages. Statistical comparisons were made using the Mann-Whitney U test (to compare the medians) or the chi-squared test (to compare the percentages). Correlations were assessed using the Spearman test and expressed using the R correlation coefficient. Statistical analysis was performed using the Statistica PL statistical package (TIBCO Software Inc. 2017, version 13, CA, USA). The level of significance was set at 0.05. stomatologicznych zazwyczaj nie zgłaszają się na wizyty kontrolne, lecz z powodów bólowych. W piśmiennictwie można znaleźć zalecenie, iż pierwsza wizyta dziecka u dentysty powinna odbyć się w ciągu 6 miesięcy od wyrznięcia się pierwszych zębów mlecznych (6). Niestety tak się nie dzieje. Najczęściej rodziców do pierwszej wizyty z dzieckiem skłania ból zęba. Takie postępowanie skutkuje brakiem zaufania małych pacjentów do stomatologa i niechęcią do współpracy (7).

\section{CEL PRACY}

Celem badania była ocena przyczyn zgłaszania się dzieci i ich rodziców na wizyty do gabinetu stomatologicznego. Dodatkowo wytyczono następujące cele badawcze:

1. określenie stanu uzębienia dzieci i ich rodziców,

2. ocena rodzaju wykonanych zabiegów u dzieci zgłaszających się do gabinetu stomatologicznego oraz rodzica, z którym przychodziły na wizyty i który także leczył się w tym samym gabinecie,

3. określenie zależności pomiędzy rodzicem a dzieckiem w zakresie stanu jamy ustnej i wykonywanych procedur medycznych.

\section{MATERIAŁ I METODY}

W badaniu przeanalizowano 162 karty pacjentów z dwóch krakowskich gabinetów stomatologicznych. Było to 81 par rodzic-dziecko (na jednego rodzica przypadało jedno dziecko), które leczyły się w tym samym gabinecie. Wizyty pacjentów odbywały się w latach 2004-2018 w 2 placówkach posiadających kontrakt z NFZ (Narodowy Fundusz Zdrowia). Analizując pierwszą wizytę pacjenta (rodzica oraz dziecka) w gabinecie sprawdzano przyczynę zgłoszenia się i oceniano stan uzębienia na podstawie diagramu zębowego przy pomocy wskaźnika PUW/puw. Jest to wskaźnik określający sumę zębów objętych próchnicą $(\mathrm{P} / \mathrm{p})$, usuniętych (U/u) oraz wypełnionych (W/w). PUW odnosi się do zębów stałych, puw do mlecznych, natomiast suma obu wskaźników służy do określania stanu uzębienia mieszanego. U dorosłych oceniano wskaźnik PUW, u dzieci odpowiednio puw i PUW+puw. Na pierwszej wizycie oraz każdej kolejnej określano wykonane świadczenia medyczne u danego pacjenta.

Każda grupa (dzieci i ich rodzice) została poddana osobnej analizie statystycznej, a także wspólnie (rodzic wraz z dzieckiem). Zmienne ciągłe przedstawiono $\mathrm{w}$ formie median i rozstępów międzykwartylowych, a zmienne kategoryczne $\mathrm{w}$ formie liczebności i udziałów procentowych. Porównania statystyczne przeprowadzono z użyciem testu U Manna-Whitneya (dla porównania median) lub na podstawie testu chi-kwadrat (dla porównania udziałów procentowych). Korelacje 


\section{RESULTS}

The most important data regarding children and parents was presented in the Table I. The age of the child during the very first visit in this particular dental office was between 2 and 17 years (median $=9$ ) while parents' age ranged from 25 to 58 years (median $=38$ ). There were 31 children aged 2 to 5 years $(38.3 \%$ of all participating children), 21 children aged 6 to 9 years (25.9\%), 15 children aged 10 to 13 years $(18.5 \%)$ and 14 children (17.3\%) aged 14 to 18 years. For 57 children (70.4\%), it was the very first visit to the dental clinic ever. According to data obtained from the parental interview, none of all examined children have come to the first adaptation visit under the age of 2 . The most of participating children were 4 to 5 years old (43.2\%) or 6 to 7 years old (34.6\%) during their very first dental visit ever. The study shows that 41 children $(72 \%)$ were diagnosed with cavities during their first visit in both participating dental offices. Only 20 of all children (24.7\%) claimed an adaptation visit, dental check-up or prophylaxis as a reason for their first visit to the office. In the remaining cases, pediatric patients came because they experienced a toothache or had dental cavities. The majority of parents, 77 of them (95\%), had active caries confirmed during their first visit. More than 3 cavities were detected in 46 cases of adult patients $(56.8 \%)$.

The DMF index for children was rated from 0 to 16 , dmf was between 0 and 17, while in the mixed oceniano używając testu Spearmana i wyrażano za pomocą współczynnika korelacji R. Analizy statystyczne wykonano za pomocą pakietu statystycznego Statistica PL (TIBCO Software Inc. 2017, version 13, CA, USA). Przyjęto poziom istotności równy 0,05 .

\section{WYNIKI}

Najważniejsze dane dotyczące rodziców i dzieci przedstawiono w Tabeli I. Wiek dziecka podczas pierwszej wizyty wynosił 2-17 lat (mediana 9), natomiast rodziców wahał się w granicach 25 do 58 lat (mediana 38 lat). Liczebność dzieci w poszczególnych przedziałach wiekowych wynosiła odpowiednio: dzieci 2-5-letnie 31 (38,3\%), 6-9-letnie - 21 (25,9\%), 10-13-letnie - 15 (18,5\%), 14-18-letnie - 14 (17,3\%). Dla $57(70,4 \%)$ dzieci była to pierwsza w życiu wizyta w gabinecie stomatologicznym. Według danych uzyskanych z wywiadu żadne $\mathrm{z}$ tych badanych dzieci nie zgłosiło się na wizytę adaptacyjną poniżej 2 roku życia. Większość dzieci odbyła pierwszą wizytę w gabinecie w wieku 4-5 lat (43,2\%) oraz w wieku 6-7 lat $(34,6 \%)$. Wśród dzieci odwiedzających po raz pierwszy gabinet stomatologiczny obecność ubytków próchnicowych stwierdzono u 41 (72\%) pacjentów. Tylko u $20(24,7 \%)$ z wszystkich badanych dzieci przyczyną wizyty była wizyta adaptacyjna, badanie kontrolne lub zabiegi profilaktyczne. W pozostałych przypadkach pacjenci zgłaszali się głównie z powodu bólu zęba lub obecności ubytków próchnicowych. W przypadku rodziców podczas ich pierwszej wizyty

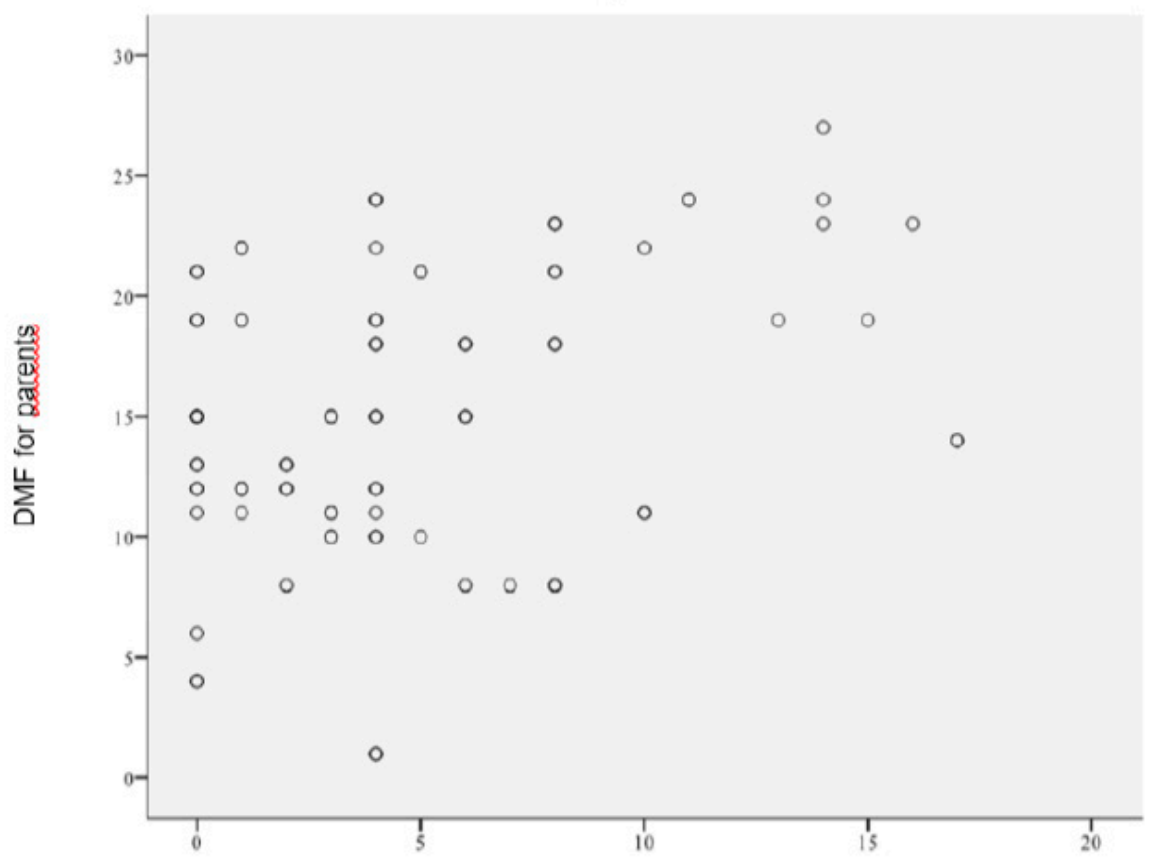

DMF for children

Figure 1. Correlation between the DMF/DMF $+\mathrm{dmf} / \mathrm{dmf}$ Index for children and the DMF index for parents Rycina 1. Korelacja pomiędzy wskaźnikem PUW/PUW+puw/puw u dzieci a wskaźnikiem PUW u rodziców 
dentition the sum of DMF and dmf was between 0 and 16. The median of DMF for children under age of 3 years old was 5, for 4-year-olds it was 4 and for 5 -year-olds it was 6 . In children with mixed dentition, the total value of DMF and dmf was 5 for children aged 6 to 7 years and 4 for children aged 11 to 13 years and older. The DMF for parents was between 1 and 27 w placówce aż u 77 (95\%) odnotowano obecność aktywnych ognisk próchnicowych, a więcej niż 3 ubytki wykryto u $46(56,8 \%)$ z nich.

Wartość PUW u dzieci mieściła się w przedziale między 0 a 16, puw między 0 a 17, natomiast w uzębieniu mieszanym PUW łącznie z puw $0-16$. Mediana puw u dzieci do 3 roku życia wynosiła 5, dla dzieci 4-letnich

Table I. Characteristic of the study group Tabela I. Charakterystyka badanej grupy

\begin{tabular}{|c|c|c|c|}
\hline & & Children & Parent \\
\hline TOTAL & & 81 & 81 \\
\hline \multirow[t]{2}{*}{ Sex } & Female & $47(58 \%)$ & $58(71.6 \%)$ \\
\hline & Male & $34(42 \%)$ & $23(28.4 \%)$ \\
\hline Time of observation & Median (range) & $14(1-43)$ & $21(2-80)$ \\
\hline \multicolumn{4}{|l|}{ Initial visit } \\
\hline $\begin{array}{l}\text { Patient age at initial } \\
\text { visit }\end{array}$ & Median (range) & $9(5-12)$ & $38(33-41)$ \\
\hline \multirow{2}{*}{$\begin{array}{l}\text { Was that ever first } \\
\text { dental visit? }\end{array}$} & Yes & $57(70.4 \%)$ & $0(0.0 \%)$ \\
\hline & No & $24(29.6 \%)$ & $81(100 \%)$ \\
\hline \multirow[t]{6}{*}{ Reason of initial visit } & Adaptation & $6(7.4 \%)$ & $0(0.0 \%)$ \\
\hline & Check-up & $8(9.9 \%)$ & $9(11.1 \%)$ \\
\hline & Prophylaxis & $6(7.4 \%)$ & $6(7.4 \%)$ \\
\hline & Cavity & $37(45.7 \%)$ & $49(60.5 \%)$ \\
\hline & Toothache & $19(23.5 \%)$ & $12(14.8 \%)$ \\
\hline & Other & $5(6.2 \%)$ & $5(6.2 \%)$ \\
\hline \multirow[t]{3}{*}{ Date of initial visit } & $2004-2009$ & $44(54.3 \%)$ & $47(58 \%)$ \\
\hline & $2010-2014$ & $37(45.7 \%)$ & $34(42 \%)$ \\
\hline & $2015-2018$ & $0(0.0 \%)$ & $0(0.0 \%)$ \\
\hline $\begin{array}{l}\text { DMF/DMF }+\mathrm{dmf} / \mathrm{dmf} \\
\text { at initial visit }\end{array}$ & Median (range) & $0(0-3.5)$ & $15(11-20)$ \\
\hline \multirow{6}{*}{$\begin{array}{lr}\text { Value } \\
\text { DMF/DMF+dmf/dmf }\end{array}$} & 0 & $15(18.5 \%)$ & $0(0.0 \%)$ \\
\hline & $1-4$ & $33(40.7 \%)$ & $4(4.9 \%)$ \\
\hline & $5-10$ & $22(27.1 \%)$ & $15(18.5 \%)$ \\
\hline & $11-16$ & $10(12.3 \%)$ & $30(37 \%)$ \\
\hline & $17-22$ & $1(1.2 \%)$ & $23(28.4 \%)$ \\
\hline & $23-27$ & $0(0.0 \%)$ & $9(11.1 \%)$ \\
\hline \multicolumn{4}{|l|}{ The length of study } \\
\hline Number of visits & Median (range) & $4(1-7)$ & $5(2-11)$ \\
\hline \multirow{3}{*}{$\begin{array}{l}\text { Avarage frequency of } \\
\text { visits }\end{array}$} & $>=1 \mathrm{x} / 6$ months & $46(56.8 \%)$ & $47(58 \%)$ \\
\hline & $1 \mathrm{x} / 6-12$ months & $14(17.3 \%)$ & $16(19.7 \%)$ \\
\hline & $<1 \mathrm{x} / 12$ months & $21(25.9 \%)$ & $18(22.2 \%)$ \\
\hline
\end{tabular}

Abbreviations: DMF/DMF+dmf/dmf - Decay-Missing-Filled Index/Decay-Missing-Filled Index + decay-missing-filled Index/decay-missing-filled Index

Skróty: DMF/DMF+dmf/dmf - wskaźnik PUW/PUW+puw/puw 
while the median was 15 . The DMF index for the child was linearly correlated with parental DMF $(r=0.348$, $\mathrm{p}=0.001)$ (Figure 1).

The median of observational time for children in this study was 14 months. Parents were observed for a longer period of time. The median was equal to 21 months. During the time of study, both children and parents reported to the dental clinic from 1 to 40 times. The median of visit frequency was 4 for children and 5 for parents. The increase in the total number of children visits to the dental clinic was associated with the increase in the number of visits of their parents $(r=0.327, p=0.003)$ (Figure 2). była równa 4 , a dla dzieci 5-letnich wynosiła 6 . U dzieci z uzębieniem mieszanym łączna wartość PUW i puw była równa 5 , u dzieci w wieku 6-7 lat oraz 4 u dzieci w wieku 11-13 lat, a także u dzieci starszych. Wartość liczby PUW u rodziców mieściła się w przedziale 1 a 27, a mediana wynosiła 15. Liczba PUW/puw/PUW+puw u dziecka korelowała dodatnio z liczbą PUW u rodzica $(\mathrm{r}=0,348, \mathrm{p}=0,001)$ (Ryc. 1).

Mediana czasu obserwacji dziecka wynosiła 14 miesięcy. Czas obserwacji rodziców był dłuższy, a mediana wynosiła 21 miesięcy. W badanym okresie zarówno dzieci, jak i rodzice zgłaszali się do gabinetu z częstością 1-40 razy, przy czym mediana u dzieci wynosiła 4 , a u rodziców 5 . Wzrost liczby wizyt dziecka w gabi-

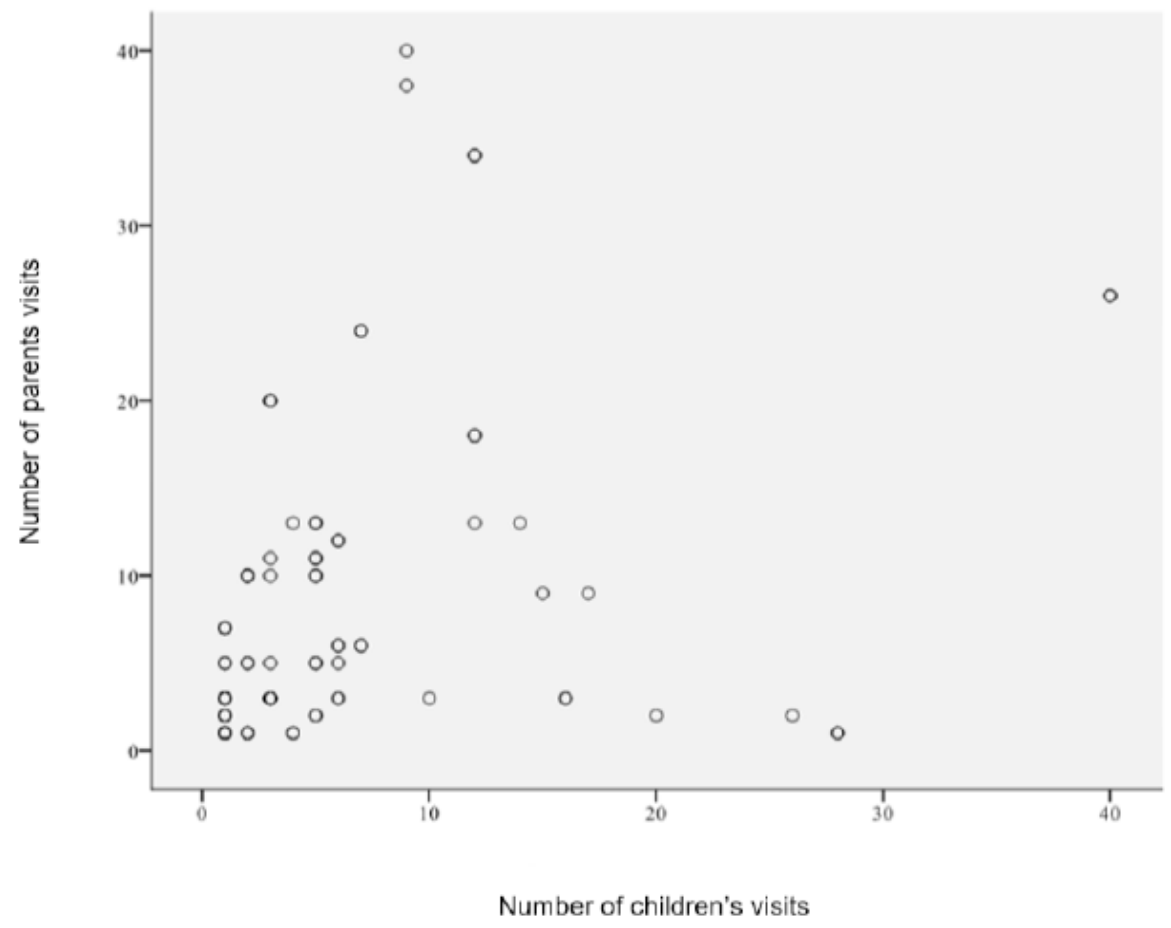

Figure 2. Correlation between the number of children's visits and the number of parents' visits Rycina 2. Korelacja pomiędzy liczbą wizyt u dzieci a liczbą wizyt u rodziców

The most frequent procedures performed for children was a prophylactic dental examination $(98.8 \%)$ and a permanent tooth filling (65.4\%). The least frequent procedure was a permanent tooth extraction (2.5\%). The most frequent procedures for adults were also permanent tooth fillings (85.2\%) and a dental examination (53.1\%). The least frequent procedures were gingival pocket rinsing, trauma related management and permanent or removable prosthetic restoration $(4.9 \%$ each). Permanent or temporary fillings in retained milk teeth were also rare $(2.5 \%)$ (Table II). necie stomatologicznym wiązał się ze wzrostem liczby wizyt rodzica $w$ gabinecie $(r=0,327, p=0,003)$ (Ryc. 2).

Podczas wizyty dziecka w placówce najczęściej wykonywano przegląd $(98,8 \%$ wizyt) oraz wypełnienie zęba stałego $(65,4 \%$ wizyt). Najrzadziej natomiast wykonywano ekstrakcję zęba stałego (2,5\%). U dorosłych również najczęściej wykonywano wypełnienie zęba stałego ( $85,2 \%$ przyczyn wizyt w gabinecie) oraz przegląd $(53,1 \%)$. Najrzadziej natomiast przeprowadzano płukanie kieszonek dziąsłowych, postępowanie w przypadku urazu, czy też wykonywano stałe lub ruchome uzupełnienia protetyczne (po 4,9\%). Także rzadko $(2,5 \%)$ zakładano wypełnienia stałe lub czasowe do przetrwałych zębów mlecznych (Tab. II). 
Table II. The number of patients with performed procedures

Tabela II. Liczba pacjentów z wykonaną procedurą

\begin{tabular}{|c|c|c|c|c|}
\hline \multirow[t]{2}{*}{ Procedure } & \multicolumn{2}{|l|}{ Child } & \multicolumn{2}{|l|}{ Parent } \\
\hline & $\begin{array}{l}\text { Number } \\
\text { (n) }\end{array}$ & $\begin{array}{l}\text { Percentage } \\
(\%)\end{array}$ & $\begin{array}{l}\text { Number } \\
\text { (n) }\end{array}$ & $\begin{array}{l}\text { Percentage } \\
(\%)\end{array}$ \\
\hline Dental examination & 80 & 98.8 & 43 & 53.1 \\
\hline Permanent tooth filling & 53 & 65.4 & 69 & 85.2 \\
\hline Milk tooth extraction & 25 & 30.9 & 0 & 0 \\
\hline Sealing & 20 & 24.7 & 0 & 0 \\
\hline Milk tooth filling & 18 & 22.2 & 2 & 2.5 \\
\hline Temporary filling in a permanent tooth & 14 & 17.3 & 39 & 48.1 \\
\hline Temporary filling in a milk tooth & 14 & 17.3 & 2 & 2.5 \\
\hline Varnishing & 12 & 14.8 & 0 & 0 \\
\hline Milk tooth pulp devitalisation & 11 & 13.6 & 0 & 0 \\
\hline Silver nitrate impregnation & 10 & 12.3 & 0 & 0 \\
\hline Temporary filling of root canals in a milk tooth & 10 & 12.3 & 0 & 0 \\
\hline Milk tooth trepanation & 8 & 9.9 & 0 & 0 \\
\hline Scaling & 7 & 8.6 & 32 & 39.5 \\
\hline Permanent tooth preparation & 4 & 4.9 & 12 & 14.8 \\
\hline $\begin{array}{l}\text { Temporary filling of root canals in a permanent } \\
\text { tooth }\end{array}$ & 4 & 4.9 & 25 & 30.9 \\
\hline Root canal filling in a permanent tooth & 4 & 4.9 & 15 & 18.5 \\
\hline Antibiotic & 4 & 4.9 & 9 & 11.1 \\
\hline Treatment of oral mucous lesions & 4 & 4.9 & 13 & 16 \\
\hline Treatment of milk tooth trauma & 3 & 3.7 & 0 & 0 \\
\hline Permanent tooth extraction & 2 & 2.5 & 17 & 21 \\
\hline Permanent tooth pulp extirpation & 2 & 2.5 & 8 & 9.9 \\
\hline Permanent tooth pulp devitalisation & 0 & 0 & 14 & 17.3 \\
\hline Denture & 0 & 0 & 4 & 4.9 \\
\hline Crown & 0 & 0 & 4 & 4.9 \\
\hline Treatment of permanent tooth trauma & 0 & 0 & 4 & 4.9 \\
\hline Periodontal pockets rinsing & 0 & 0 & 4 & 4.9 \\
\hline
\end{tabular}

\section{DISCUSSION}

According to the recommendations of the American Academy of Pediatric Dentistry (AAPD) (8) and the American Dental Association (ADA) (6), the first dental visit of a child should take place within 6 months after the eruption of the first milk teeth, but not later than at the age of 12 months. A similar age of first dental visit is also indicated by experts from the Polish Association of Pediatric Dentistry (9). The first visit should be an adaptation visit, during which the child can get to know the clinic. It also should concentrate on parental education regarding proper oral hygiene

\section{DYSKUSJA}

Zgodnie z zaleceniami Amerykańskiej Akademii Stomatologii Dziecięcej (American Academy of Pediatric Dentistry - AAPD) (8) i Amerykańskiego Towarzystwa Stomatologicznego (American Dental Association - ADA) (6) pierwsza wizyta stomatologiczna dziecka powinna odbyć się w ciągu 6 miesięcy od wyrznięcia pierwszych zębów mlecznych, ale nie później niż do ukończenia pierwszego roku życia. Na podobny przedział wiekowy wskazują także eksperci z Polskiego Towarzystwa Stomatologii Dziecięcej (9). Pierwsza wizyta dziecka w gabinecie powinna być wizytą adaptacyjną, 
of a child, prophylactic procedures and basic dietary recommendations. The study shows that parents do not come to dental clinics with little children in order to get them acquainted with the clinic, have a regular checkup or undergo prophylactic procedures. In this study, an average age of a child during the first ever visit was 9 years old. Therefore, a few years old children visit dentist for the very first time instead of infants. Most children who come to the clinic already have oral cavities. Only $28 \%$ of the very first-time patients did not have any caries lesions.

The high prevalence of caries in the youngest children is associated with their late introduction to preventive and therapeutic programmes (10). According to the study conducted by I. Grzesiak and U. Kaczmarek, only $33 \%$ of children in the age bracket of 1.5 to 3 years had their first contact with a dentist, with the average age of 32 months during their first visit (11). The nation-wide data shows that $61.5 \%$ of 3 -year-old children have not yet been seen by a dentist (12). Also authors from other countries obtained similar results in their studies. Slayton et al. in their studies conducted in the USA, confirm that only $2 \%$ of parents report that their child had first contact with a dentist before the age of 12 months (7). According to Indian authors, $57 \%$ out of 300 participating children in the study, had their first dental visit between age of 6 and 9 . Only $3 \%$ of children came to their first dental visit to the age of 0 to 3 years (13).

In this study, a vast majority of children (75.3\%) visited the dental clinic due to a toothache or a defect caused by caries. This is consistent with the results of studies carried out by other authors. According to Wilk-Sieczak et al., in the study group consisting of 100 children aged 3 to 6 only $26.3 \%$ of patients came for a check-up or an adaptation visit. The remaining children reported to the office with dental problems and symptoms (14). Murshid states that $71.5 \%$ of the cases, dental visits were related to complains of having various types of pain (15).

High values of caries index obtained in this study confirm the scale of the disease. The average value of $\mathrm{DMF} / \mathrm{dmf} / \mathrm{DMF}+\mathrm{dmf}$ for children under 3 years of age was 5, for 4-year-olds it was 4, for 5-year-olds it was 6 and for 6 to 7-year-olds it was 5. For children aged 11-13 years and older, DMF was 4 on average. This is consistent with the results of other studies conducted in Poland. In 2003, a socio-epidemiological study conducted under the auspices of the Ministry of Health confirmed that about half of 12-year-old children had 4 or more teeth affected by caries. Between 2 and 3 years of age caries of milk teeth occurs in $35-50 \%$ of children, between 3 and 4 years of age caries occurs in $56-60 \%$ of children, and at the age of 6-7 years in almost $100 \%$ of children (16). The mean value of dmf na której dziecko może zapoznać się z gabinetem stomatologicznym. Służy ona także edukacji opiekunów w zakresie prawidłowej higieny jamy ustnej dziecka, zabiegów profilaktycznych oraz przekazaniu podstawowych zaleceń dietetycznych. Z przeprowadzonego badania wynika, iż rodzice nie przychodzą na wizyty stomatologiczne w celu oswojenia dziecka z gabinetem oraz wykonania przeglądu uzębienia czy przeprowadzenia świadczeń profilaktycznych. Średni wiek dziecka podczas pierwszej wizyty wynosił 9 lat. Zatem bardzo często do lekarza dentysty po raz pierwszy w życiu trafiają kilkulatkowie, a nie niemowlaki. Najczęściej do gabinetu przychodzą dzieci już ze skutkami choroby próchnicowej. Tylko u $16(28 \%)$ z pierwszorazowych pacjentów nie stwierdzono obecności ubytków.

Wysoka częstość występowania próchnicy u najmłodszych dzieci jest związana z późnym ich objęciem działaniem zapobiegawczo-leczniczym (10). Według badań przeprowadzonych przez I. Grzesiak i U. Kaczmarek u dzieci w wieku 1,5-3 lat pierwszy kontakt ze stomatologiem miało $33 \%$ dzieci w wieku wynoszącym średnio 32 miesiące (11). $Z$ danych uzyskanych w skali kraju dla dzieci 3-letnich wynika, że $61,5 \%$ z nich nie było dotychczas u stomatologa (12). Także autorzy z innych krajów uzyskali w swoich badaniach podobne wyniki. Slayton i wsp. w badaniach przeprowadzonych w USA podają, iż tylko według $2 \%$ rodziców ich dziecko miało pierwszy kontakt z lekarzem dentystą przed ukończeniem 12 miesięcy (7). Według indyjskich autorów z przebadanych 300 dzieci aż 57\% odbyło pierwszą wizytę stomatologiczną w wieku 6-9 lat. Tylko 3\% dzieci zgłosiło się na pierwszą wizytę stomatologiczną w wieku 0-3 lat (13).

W przeprowadzonym badaniu $\mathrm{w}$ zdecydowanej większości $(75,3 \%)$ przyczyną wizyty dziecka w gabinecie stomatologicznym był ból zęba lub obecność ubytków próchnicowych. Jest to zgodne z wynikami badań innych autorów. Według Wilk-Sieczak i wsp. w grupie badanej obejmującej 100 dzieci w wieku 3-6 lat tylko $26,3 \%$ pacjentów przyszło na wizytę kontrolną lub adaptacyjną. Pozostałe dzieci były pacjentami symptomatycznymi (14). Murshid podaje, iż przyczyną zgłoszenia się dziecka na wizytę stomatologiczną były w 71,5\% przypadków różnego rodzaju dolegliwości bólowe (15).

Wysokie wartości wskaźników próchnicy uzyskane badaniu świadczą o skali problemu jakim jest ta choroba. Przeciętna wartość PUW/puw/PUW+puw u dzieci do 3 roku życia wynosiła 5, dla dzieci 4-letnich była równa 4 , dla dzieci 5-letnich wynosiła 6 , a dla dzieci w wieku 6-7 lat była równa 5. U dzieci w wieku 11-13 lat i starszych PUW było przeciętnie równe 4. Jest to zgodne z wynikami innych polskich badań. W 2003 r. pod patronatem Ministerstwa Zdrowia przeprowadzono badania socjoepidemiologiczne, na podstawie któ- 
in the study (2011) by J. Szymańska and L. Szalewski was as follow. The dmf for 3-year-old children was 2.13-5.31, 3.79 for 4-year-olds, 4.41-4.67 for 5-yearolds and 5-6.17 for 6-year-olds (17). Among European countries, the best condition of dentition was found in 12-year-old children in the Netherlands $(\mathrm{DMF}=0.9)$ and the worst in Latvia $(\mathrm{DMF}=7.7)$. Poland with the DMF index of 4.4 occupies the next to the last place (16).

A statistical Polish child at the age of 5 years has on average about 5 teeth with untreated caries. The proportion of children at the age of 5 without caries reaches $20 \%$ (18). Poland is one of the few European countries where the incidence of caries in children has not been reduced, despite the World Health Organization (WHO) guidelines. According to the WHO recommendations for the year 2000, the incidence of caries in 6-year-old children should be reduced to $50 \%$. The WHO health objective for 2020 was even more challenging. The number of 6-yearold children without caries should reach $80 \%$ in all European countries and is even more difficult to achieve in the Polish population (17). The results of the National Monitoring of Oral Health and Its Conditions show that the incidence of caries tends to increase with the age of the child from $41.1 \%$ in children aged 3 (2017) to $76.8 \%$ in the group of 5 -year-olds (2016), $81.6 \%$ in the 6-year-old group (2018), $89.4 \%$ in the 7-year-old group (2016), and up to $93.2 \%$ in the 18 -year-old youth (2017) (19).

In this study, the median of the DMF for parents was 15 , which indicates intensification of caries disease and teeth decays. Additionally, it has been shown that the increase of $\mathrm{DMF} / \mathrm{dmf} / \mathrm{DMF}+\mathrm{dmf}$ for the child was associated with the increase of DMF for the parent. A similar correlation was also observed in regards of the number of visits and observation time at the dental clinic. The above data suggests a close relationship between the oral health status and prohealth behaviour in parents and their children. Adults who come for regular dental visits also regularly bring their children to follow-up visits. On the other hand, patients who rarely use dental services do not come to regular visits with their own children. Pain is the main reason to visit a dental office.

Many authors point out a similar corelation between children and their parents' behaviours. Moallemi et al. in their studies reveal that tooth-brushing twice a day and healthy teeth in 9-year-olds were associated with pro-health oral instruction on hygiene and diet offered to their mothers (20). Parents of children with caries consumed more food and drinks containing carbohydrates, they also brushed their teeth less frequently as compared to parents of children without caries. A strong corelation was found between parental rych stwierdzono, że około połowa dzieci w wieku 12 lat miała 4 i więcej zębów objętych próchnicą. Między 2 a 3 r.ż. próchnica zębów mlecznych występowała u 35-50\% dzieci, między 3 a 4 r.ż. aż u 56-60\% a w wieku 6-7 lat u prawie $100 \%$ dzieci (16). Średnia wartość puw w badaniu J. Szymańskiej i L. Szalewskiego z 2011 roku wynosiła 2,13-5,31 u 3 latków, 3,79 u 4 latków, 4,41-4,67 u 5 latków, 5-6,17 u 6 latków (17). Wśród krajów europejskich najlepszy stan uzębienia u 12 latków stwierdzono w Holandii (PUW=0,9), a najgorszy na Łotwie (PUW=7,7). Polska ze wskaźnikiem PUW wynoszącym 4,4 zajmuje przedostatnie miejsce (16).

Statystyczne polskie dziecko w wieku 5 lat ma średnio około 5 zębów z nieleczonymi ubytkami próchnicowymi, a odsetek dzieci w wieku 5 lat bez próchnicy sięga 20\% (18). Polska jest jednym z niewielu krajów Europy, w którym nie udało się zmniejszyć zapadalności na próchnicę u dzieci, pomimo zaleceń Światowej Organizacji Zdrowia (WHO) na rok 2000, według których częstość występowania próchnicy u dzieci 6-letnich powinna być zredukowana do $50 \%$. Jeszcze trudniejszy do zrealizowania w populacji polskiej okazał się cel zdrowia WHO na 2020 rok, który zakładał, że we wszystkich krajach europejskich odsetek dzieci 6 letnich bez próchnicy ma sięgnąć 80\% (17). Wyniki Ogólnopolskiego Monitoringu Stanu Zdrowia Jamy Ustnej i Jego Uwarunkowań pokazują, że częstość występowania próchnicy ma tendencję wzrostową wraz z wiekiem dziecka od 41,1\% u dzieci w wieku 3 lat (2017 rok) do 76,8\% w grupie dzieci 5-letnich (2016 rok), 81,6\% w grupie 6-letnich (2018 rok), 89,4\% 7-letnich (2016 rok), aż do 93,2\% u młodzieży 18-letniej (2017 rok) (19).

W przeprowadzonym badaniu mediana PUW u rodziców wynosiła 15 , co świadczy o dużym nasileniu choroby próchnicowej także wśród opiekunów badanych dzieci. Dodatkowo wykazano, że PUW/puw/ PUW+puw u dziecka korelowało dodatnio z PUW $\mathrm{u}$ jego rodzica. Także liczba wizyt $\mathrm{w}$ gabinecie stomatologicznym u dziecka korelowała dodatnio z liczbą wizyt u rodzica. Powyższe dane sugerują ścisły związek pomiędzy stanem zdrowia jamy ustnej i zachowaniami prozdrowotnymi u rodziców i ich dzieci. Osoby dorosłe przychodzące na regularne wizyty stomatologiczne również regularnie przyprowadzają swoje dzieci na wizyty kontrolne. Natomiast pacjenci rzadko korzystający z usług dentysty nie zgłaszają się ze swoimi dziećmi na regularne wizyty - są one głównie z przyczyn bólowych.

Wielu autorów wskazuje na zależność pomiędzy zachowaniami dzieci i ich opiekunów. Saied Moallemi i wsp. w swoich badaniach podają, iż dwukrotne codzienne szczotkowanie zębów i zdrowe uzębienie u 9-latków były związane z edukacją prozdrowotną matek w zakresie diety i higieny jamy ustnej (20). Rodzice dzieci, u których występowała choroba próchnicowa 
practices, interaction between parents and children and childhood caries (21).

According to the study by Camargo et al., children whose mothers declared that they went to the dentist on a regular basis had a 2.5 -fold higher rate of regular visits than those whose mothers visited the dentist irregularly (3). Awareness and parents' need of dental treatment play an important role in the development of caries in the child. The study by Moimaz et al. shows that the presence of caries in a child depends less on socio-economic factors and more on the mother's need of dental treatment (1).

Caries is a very common disease, and its prevention and prophylactic treatments are the bases of dental care (1). In this study, the most frequently performed procedures at the clinic, for both in children and parents, were an oral cavity examination and a tooth filling. In many patients, especially children, prophylactic procedures, such as sealing and varnishing, were also performed.

\section{CONCLUSIONS}

The study showed that the dental health of both children and their parents was unsatisfactory. Due to the prevalence of caries, the dentist's intervention focuses mainly on prophylaxis and treatment of caries.

It is necessary to introduce educational programmes focused on dental prophylaxis to make patients more aware of the importance of regular visits to the dental clinic and proper oral health routines. Such education should be offered both to children and their parents. The oral health of children depends, to a large extent, on their caregivers who are responsible for shaping proper health habits. Children of parents who regularly visit dental clinics also come more often for checkups and undertake systematic treatments. In wellorganised health care systems, medical staff should provide information on the prevention of caries in the youngest children. This applies not only to dentists, but also pediatricians, gynaecologists and middlelevel medical staff.

\section{REFERENCES}

1. Moimaz SA, Fadel CB, Lolli LF, et al. Social aspects of dental caries in the context of motherchild pairs. J Appl Oral Sci. 2014;22(1):73-8.

2. Fisher J, Johnston S, Hewson N, et al. FDI Global Caries Initiative; implementing a paradigm shift in dental practice and the global policy context. Int Dent J. 2012 62(4):169-74.

3. Camargo MB, Barros AJ, Frazao P, et al. Predictors of dental visits for routine check-ups and for the spożywali więcej pokarmów i napojów zawierających węglowodany oraz rzadziej szczotkowali zęby w porównaniu z rodzicami dzieci bez choroby próchnicowej. Stwierdzono silny związek pomiędzy praktykami rodzicielskimi, interakcją między rodzicami i dziećmi, a próchnicą wieku dziecięcego (21).

Według badań Camargo i wsp. dzieci, których matki deklarowały, że chodzą do dentysty systematycznie, miały 2,5 razy wyższy wskaźnik regularnych wizyt niż te, których matki odwiedzały gabinet nieregularnie (3). Duże znaczenie w rozwoju próchnicy u dziecka odgrywa świadomość i potrzeba leczenia stomatologicznego u rodziców. Z badań Moimaz i wsp. wynika, że obecność próchnicy u dziecka zależy w mniejszym stopniu od czynników socjoekonomicznych, a w większym od potrzeby leczenia stomatologicznego u matek.

Próchnica jest bardzo powszechną chorobą, a jej profilaktyka i leczenie zachowawcze ubytków próchnicowych jest podstawą opieki stomatologicznej (1). $\mathrm{W}$ badaniu procedurami najczęściej wykonywanymi w gabinecie, zarówno u dzieci jak i rodziców, były badanie jamy ustnej oraz wypełnienia zębów. U wielu pacjentów, zwłaszcza w grupie dzieci, wykonano także procedury profilaktyczne, takie jak lakowanie i lakierowanie.

\section{WNIOSKI}

Badanie wykazało, że stan zdrowia zębów zarówno u dzieci jak i u ich rodziców był niezadowalający. W związku z powszechnością choroby jaką jest próchnica, działanie lekarza dentysty skupia się głównie na jej leczeniu.

Istnieje potrzeba wprowadzenia programów edukacyjnych koncentrujących się na profilaktyce stomatologicznej oraz uświadomieniu pacjentom jak ważną rolę dla zapewnienia prawidłowego stanu zdrowia jamy ustnej odgrywają regularne wizyty w gabinecie stomatologicznym. Edukacja ta powinna dotyczyć zarówno dzieci, jak i ich rodziców. Zdrowie jamy ustnej dzieci w dużej mierze zależy od ich opiekunów, którzy są odpowiedzialni za kształtowanie prawidłowych nawyków zdrowotnych. Dzieci rodziców odwiedzających regularnie gabinet stomatologiczny także przychodzą częściej na wizyty kontrolne i podejmują systematyczne leczenie. W dobrze zorganizowanych systemach opieki zdrowotnej personel medyczny powinien przekazywać informacje na temat profilaktyki próchnicy u najmłodszych. Dotyczy to nie tylko dentystów, ale także pediatrów, ginekologów i średniego personelu medycznego. 
resolution of problems among preschool children. Rev Saude Publica. 2012;46(1):87-97.

4. Tanner ACR, Milgrom PM, Kent R, et al. Similarity of the oralmicrobiota of pre-school children with that of their caregivers in a population- based study. Oral Microbiology Immunology. 2003;17:379-87.

5. Ravikumar D, Ningthoujam S, Robindro W, et al. Genotypic characterization of Streptococcus mutans in child-mother pair-A PCR based study. J Oral Biol Craniofac Res. 2018;8(3):225-30.

6. American Dental Association. Statement on early childhood caries; http://www.ada.org/en/aboutthe-ada/ada-positions-policies-and-statements/ statement-on-earlychildhood-caries

7. Slayton RL, Warren JJ, Levy SM, et al. Frequency of reported dental visits and professionals fluoride application in a cohort of children followed from birth to 3 years. Pediatr Dent. 2002;24:64-8.

8. American Academy of Pediatric Dentistry: Guideline on infant oral health care. Pediatr Dent. 2014;36(6(1)):1141-45.

9. Polish Paediatric Dentistry Association. Oral hygiene recommendations for children and adolescents in subsequent age group. https://ptsd. net.pl/wp-content/uploads/2017/05/Zalecenia_w_ zakresie_higieny_jamy_ustnej_dla_dzieci_i ${ }^{-}$ mlodziezy_w_kolejnych_grupach_wiekowych. pdf.

10. Grzesiak I, Kaczmarek U. Pierwsza wizyta dziecka w gabinecie stomatologicznym. Dent Med Probl. 2006;43(3):433-7.

11. Grzesiak I. Wieloczynnikowa analiza uwarunkowań próchnicy wczesnej u dzieci. Praca doktorska. Wrocław, Polska: Wrocławski Uniwersytet medyczny 2004.

12. Wierzbicka M, Szatko F, Zawadziński M, et al. Nationwide monitoring of the oral health status and its conditionings. Poland 2003. Ministry of Health 2004.

13. Sanguida A, Vinothini V, Prathima GS, et al. Age and Reasons for First Dental Visit and Knowledge and Attitude of Parents Toward Dental Procedures for Puducherry Children Aged 0-9 years. J Pharm Bioallied Sci. 2019;11:413-9.

14. Wilk-Sieczak B, Zakrzewski M, ChmielewskaŁuczak D. Lęk matek przed leczeniem stomatologicznym i przyczyna pierwszej wizyty dziecka a czynniki prognozowania negatywnej postawy dziecka w wieku przedszkolnym podczas leczenia stomatologicznego. Dent Med Prob. 2005;42(1):77-82.

15. Murshid EZ. Children's ages and reasons for receiving their first dental visit in a Saudi community. Saudi Dent J. 2016;28:142-7.

16. Pawka B, Dreher P, Herda J, et al. Próchnica zębów u dzieci problemem społecznym. Probl Hig Epidemiol. 2010;91(1):5-7.

17. Szymańska J, Szalewski L. Próchnica zębów mlecznych w populacji dzieci polskich. Zdr Publ. 2011;121(1):86-9.

18. Szatko F, Rabęda A, Bromblik A. Ocena skuteczności systemu opieki stomatologicznej na podstawie analizy porównawczej stanu uzębienia $\mathrm{i}$ potrzeb stomatologicznych dzieci $\mathrm{w}$ wieku przedszkolnym. Czas Stomatol. 2008;61(1):61-8.

19. Ministerstwo Zdrowia. https://www.gov.pl/web/ zdrowie/monitorowanie-stanu-zdrowia-jamyustnej-populacji-polskiej-w-latach-2016-2020

20. Saied-Moallemi Z, Virtanen JI, Ghofranipour F, et al. Influence of mothers' oral health knowledge and attitudes on their children's dental health. Eur Arch Paediatr Dent. 2008;9(2):79-83.

21. de Jong-Lenters M, Duijster D, Bruist MA, et al. The relationship between parenting, family interaction and childhood dental caries: a casecontrol study. Soc Sci Med. 2014;116:49-55.

\section{Received: 20.04.2021}

Accepted for publication: 06.10.2021

Otrzymano: 20.04.2021 r.

Zaakceptowano do publikacji: 06.10.2021 r.

\section{Address for correspondence:}

Adres do korespondencji:

Dr n. med. Joanna Waligóra

Katedra Stomatologii Zintegrowanej UJ CM

ul. Montelupich 4, 31-155 Kraków

Tel. 607584204

E-mail: joanna.waligora@uj.edu.pl 